\title{
Sharia Hospital Management in Terms of Religion Surveillance Aspect in Yogyakarta
}

\author{
Hasnah Rimiyati ${ }^{1, *}$ Susanto $^{2}$ \\ ${ }^{1}$ Management Study Program, Faculty of Economics, Universitas Muhammadiyah Yogyakarta, Yogyakarta \\ ${ }^{2}$ Management Study Program, Faculty of Economics, Universitas Sarjana Wiyata Taman Siswa, Yogyakarta \\ *Corresponding author. Email: hasnah_rimiyati@umy.ac.id
}

\begin{abstract}
The research objectives were to analyze the service implementation performance at the "X" Hospital in Bantul Yogyakarta, which has met the requirements as a Sharia Hospital, is the first hospital in Yogyakarta to obtain a Sharia Hospital certification from the Indonesian Ulema Council (MUI), and has implemented Maqashid Sharia principles. This research design used qualitative and quantitative approaches. Qualitative data analysis was carried out to obtain a comprehensive picture of hospital policy implementation, while quantitative analysis was conducted to determine hospital performance achievements. Questionnaires and interviews were employed for data collection. Hospital performance assessment was performed based on the Sharia Management Standard and Sharia Service Standard group. The assessment for the Sharia Management Standard group obtained the following results: (1) The obtained value from the Sharia Management Organization Standard (SSMO) assessment result was stated fully achieved. (2) The result of the Marketing Management Sharia Standard (SSMP) assessment stated that the obtained value was partially attained. (3) The assessment result of the Sharia Standard for Facility Management (SSMF) revealed that the obtained value was declared partially reached. (4) For the Quality Management Sharia Standard (SSMM) assessment result, the obtained value was partially accomplished. Furthermore, the assessment for Sharia Service Standards uncovered that (1) The result of the Sharia Standards for Service Access and Continuity (SSAPK) assessment stated that the obtained value was fully reached. (2) The assessment result of the Sharia Standard for Patient Assessment (SSAP) indicated that the obtained value was declared fully realized. (3) Concerning the Sharia Standard for Patient Service (SSPP) assessment, the result showed that the obtained value was fully achieved. (4) The obtained value from the Sharia Medicine Service Standards (SSPO) assessment result was asserted partially achieved. (5) As for the Sharia Standard for Service and Spiritual Guidance (SSPBK) assessment result, the obtained value was fully attained. Finally, (6) The results of the Sharia Standard (SSPPK) assessment declared that the obtained value was fully accomplished.
\end{abstract}

Keywords: Sharia Hospital Management, Services, Hospital Performance.

\section{INTRODUCTION}

The prospect of developing sharia hospitals has considerable potential that can be seen by developing the Muslim community's contribution to the health service market in several countries, which quantitatively has the potential to be developed. From this fact, the prospect of Sharia Hospital indicates that it is very promising from a social and business perspective. Several countries have implemented the concept of sharia hospitals, including Malaysia, Singapore and Indonesia. According to the Deputy Minister of Tourism and Creative Economy (Parekraf), Indonesia has a great opportunity, both in terms of market availability and resource availability, to be developed because around $88 \%$ of Indonesian citizens are Muslim, meaning that $88 \%$ of Indonesia has the potential to develop sharia hospitals.

Indonesia has great potential to support the development of sharia hospitals. The current government presence in developing sharia hospitals is to regulate, facilitate, and disseminate information about sharia hospitals so that people can better understand them. In developing sharia hospitals in Indonesia, several obstacles are still encountered, among others, the insufficient resources of medical personnel to meet Sharia hospital standards' adequacy. Even though the 
government has planned to develop sharia hospitals, there are still differences in perceptions of accepting sharia hospitals.

So far, the Ministry of Health with several related parties has agreed on sharia hospital standards, including standards that hospitals must meet in accordance with Islamic Sharia principles [6]. Currently, these standards have been implemented and are quite effective in hospitals, such as the provision of prayer equipment, Qibla direction during prayers, provision of halal-certified food, and others. The development of sharia hospitals in several regions in Indonesia has started and will continue to grow, for example, in Semarang with a sizeable Muslim population.

Furthermore, hospitals are understood as institutions that provide health services in the form of inpatient, outpatient, and emergency services. Meanwhile, what is meant by sharia is the law that regulates life from all aspects of being a Muslim, which determines halal and haram matters in life [1]. The objectives of Sharia [2] are described in five aspects: Hifzh Ad-Din (protection of religion), Hifzh An-Nafs (protection of life), Hifzh $A n$-'Aql (protection of the mind), Hifzh An-Nasl (protection of descendants), and Hifzh Al-Maal (protection of wealth). Thus, a sharia hospital is defined as an organization with a scope of work, policies, procedures, and employment requirements according to Sharia principles in totality [3],[4].

However, dissatisfaction with hospital services can cause patients to no more prolonged use of health services, resulting in a decreased number of patients and hospital income [5].

According [6], service is an essential factor, especially for organizations engaged in services. Services are determined by management; good management and in accordance with the provisions will make the service good, especially in accordance with Islamic Sharia so that the management becomes Sharia management[7],[8].

The sustainable, effective, and fair performance appraisals willincrease employee motivation and performance. Defines performance as theresults of the job function or activity of a person or group in an organization that is influenced by various factors to achieve organizational goals within a specific period [10].

From these backgrounds and problems, several questions related to sharia hospitals could be posed, as follows:

1.1. How is the governance of the " $X$ " hospital in Bantul as one of the sharia hospitals in Yogyakarta?

1.2. How is the service implementation performance of "X" sharia hospital in Bantul, Yogyakarta?

\section{METHOD}

\section{Research Approach}

This research at " $\mathrm{X}$ " sharia hospital used qualitative and quantitative approaches. A qualitative approach was employed to study sharia hospital governance. Meanwhile, a quantitative approach was utilized to see hospital performance, using questionnaires and interviews distributed to respondents (managers).

\section{Object of Research}

The research object was the " $\mathrm{X}$ " sharia hospital in Bantul, Yogyakarta Special Region. The "X" hospital's selection was based on the consideration that the hospital had obtained a sharia hospital certification from the Indonesian Ulema Council (MUI).

\section{Data Collection Technique}

The data collection techniques employed in this study were participant observation, questionnaires, and in-depth interviews with hospital administrators, supported by "X" hospital documentation.

\section{Data Analysis}

Data analysis to answer the existing problems used a qualitative descriptive approach and quantitative analysis using a percentage. The assessment provisions referred to the Hospital Accreditation Standard (KARS) [9].

\section{RESULTS AND DISCUSSION}

The descriptive statistical analysis results of each standard were presented to determine the average assessment of each standard analyzed in this study, using the following intervals:

Interval $=($ highest score-lowest score $) /$ Maximum value

$$
=(10-0) / 3=3,33
$$

Based on this interval, it could be interpreted from each class and is presented in Table 1 below:

Table 1. Interval Class Interpretation

\begin{tabular}{|l|l|}
\hline \multicolumn{1}{|c|}{ Interval } & \multicolumn{1}{c|}{ Interpretation } \\
\hline$<3,33$ & Low \\
\hline$>3,33-6,66$ & Moderate \\
\hline$>6,66$ & High \\
\hline
\end{tabular}




\section{Analysis Results}

The analysis was performed based on the Sharia Management Standard Group, which consists of the Organization Management Sharia Standard (SSMO), the Marketing Management Sharia Standard (SSMP), the
Facility Management Sharia Standard (SSMF), and the Quality Management Sharia Standard (SSMM).

The results of the Organization Management

Sharia Standard Assessment (SSMO) are

displayed in Table 2 below:

Table 2. Analysis Results of SSMO Standards

\begin{tabular}{|c|c|c|c|c|c|}
\hline Standard & $\begin{array}{l}\text { Obtained } \\
\text { value }\end{array}$ & $\begin{array}{l}\text { Maximum standard } \\
\text { of the obtained value }\end{array}$ & $\begin{array}{c}\text { Average } \\
\text { obtained } \\
\text { value }\end{array}$ & $\begin{array}{c}\text { Achievement } \\
\text { s }(\%)\end{array}$ & Description \\
\hline SSMO1 & 30 & 30 & 10 & 100 & High \\
\hline SSMO2 & 25 & 30 & 8,33 & 83,33 & High \\
\hline SSMO3 & 30 & 30 & 10 & 100 & High \\
\hline SSMO4 & 10 & 10 & 10 & 100 & High \\
\hline SSMO5 & 30 & 30 & 10 & 100 & High \\
\hline SSMO6 & 25 & 30 & 8,33 & 83,33 & High \\
\hline SSMO7 & 30 & 30 & 10 & 100 & High \\
\hline SSMO8 & 25 & 30 & 8,33 & 83,33 & High \\
\hline SSMO9 & 45 & 50 & 9,00 & 90,00 & High \\
\hline
\end{tabular}

The assessment results presented in Table 2. show that the obtained values are as follows:

1) From the responsibility and accountability aspects of the hospital owner (SSMO-1), the value was $100 \%$, meaning that the obtained value was fully achieved. The "X" Bantul sharia hospital owner was fully responsible for the Organization Management Sharia Standards, supported by complete documents

2) From the Sharia Supervisory Board (DPS) aspect (SSMO-2), the value was $83.33 \%$, indicating that the obtained value was not fully attained but still needs to be completed. The owner of the " $\mathrm{X}$ " Bantul sharia hospital has established a Sharia Supervisory Board (DPS) in supervising hospital operations, was in accordance with their duties and responsibilities according to sharia principles, and was supported by written documents.

3) From the Hospital by Low (SSMO3) aspect, the value was $100 \%$, denoting that the obtained value was fully reached. The owner of the sharia hospital "X" Bantul legally complied with the legal rules applicable to sharia hospitals.

4) From the Vision and Mission (SSMO4) aspect, the value was $100 \%$, signifying that the obtained value was fully accomplished. Judging from the vision and mission, the "X" Bantul sharia hospital contained Islamic values explicitly.

5) From the Sharia Service Operations Committee (SSMO5) aspect, the value was $100 \%$. It indicated that the obtained value was fully attained, judged from the management, organizational structure, and work program in accordance with sharia hospitals.
6) From the mosque management institution (SSMO6) aspect, the value was $83.33 \%$, denoting that the obtained value was close to being fully reached. The management institution of the mosque/Islamic prayer room, organizational structure, and work programs have been assessed in accordance with sharia hospitals.

7) From the Spiritual Sector Structure (SSMO7) aspect, the value was $100 \%$, signifying that the obtained value was fully achieved. It was assessed from the management of the spiritual field, the organizational structure of the spiritual sector, and the work program, which was in accordance with the sharia hospital.

8) From the Code of Conduct Guidelines (SSMO8) aspect, the value was $83.33 \%$. It indicated that the obtained value was close to being fully attained, judged by the hospital code of ethics, hospital policy, and implementation in work programs in accordance with sharia hospitals.

9) From the Sharia Contract (SSMO9) aspect, a value of $90 \%$ was obtained, meaning that the obtained value was close to being fully reached. The implementation of the hospital contract with Insani Human Resources (SDI), with patients, with suppliers of medical devices and laboratories, with drug and logistics suppliers, financial institutions, and other related institutions, was considered to be in accordance with sharia hospitals.

The results of the Marketing Management Sharia Standard Assessment (SSMP) are presented in Table 3 below: 
Table 3. Assessment Results of Marketing Management Sharia Standards (SSMP)

\begin{tabular}{|c|c|c|c|c|c|}
\hline Standard & Obtained value & $\begin{array}{c}\text { Maximum } \\
\text { standard of the } \\
\text { obtained value }\end{array}$ & $\begin{array}{c}\text { Average } \\
\text { obtained value }\end{array}$ & $\begin{array}{c}\text { Achievement } \\
\text { s (\%) }\end{array}$ & Description \\
\hline SSMP1 & 30 & 40 & 7,50 & 75 & High \\
\hline SSMP2 & 30 & 40 & 7,50 & 75 & High \\
\hline
\end{tabular}

The assessment results displayed in Table 3. reveal the obtained values as follows:

1) From the Marketing Governance aspect, a value of $75 \%$ was obtained, meaning that the obtained value was partially achieved, judging from the policies, guidelines and procedures for marketing hospitals, hospital service products, riswah (bribes) in the process of offering cooperation, and cooperation with other parties in accordance with the principles sharia hospital.
2) From the aspect of Health Service Promotion to the community, a value of $75 \%$ was obtained, meaning that the obtained value was partially reached, which was assessed from marketing governance, service promotion, media promotion, and the Sharia committee's involvement recommendations for sharia marketing governance.

The results of the Facility Management Sharia Standard Assessment (SSMF) are displayed in Table 4 below:

Table 4. Sharia Standards for Facility Management (SSMF)

\begin{tabular}{|l|c|c|c|c|c|}
\hline Standard & Obtained value & $\begin{array}{c}\text { Maximum standard of } \\
\text { the obtained value }\end{array}$ & $\begin{array}{c}\text { Average } \\
\text { obtained value }\end{array}$ & $\begin{array}{c}\text { Achievement } \\
\text { s (\%) }\end{array}$ & Description \\
\hline SSMF & 50 & 80 & 6,25 & 62,5 & Moderate \\
\hline
\end{tabular}

The assessment result presented in Table 4. shows the obtained value as follows:

From the aspect of Facility Standards, a value of $62.5 \%$ was obtained. It suggested that the obtained value was partially accomplished, assessed from the implementation of standard facilities, rooms, wards, laundry, bathroom maintenance, washing water and

drinking water, provision of religious facilities, and halal kitchen management, which has been in accordance with the rules of the sharia hospital.

The results of the Quality Management Sharia Standard (SSMM) assessment are presented in Table 5 below:

Table 5. Sharia Standards for Quality Management (SSMM)

\begin{tabular}{|l|c|c|c|c|c|}
\hline Standard & Obtained value & $\begin{array}{c}\text { Maximum standard of } \\
\text { the obtained value }\end{array}$ & $\begin{array}{c}\text { Average } \\
\text { obtained value }\end{array}$ & $\begin{array}{c}\text { Achievement } \\
\text { s (\%) }\end{array}$ & Description \\
\hline SSMM & 55 & 70 & 7,86 & 78,6 & High \\
\hline
\end{tabular}

The assessment result displayed in Table 5. reveals the obtained value as follows:

From the aspect of Quality Standards, a value of $78.6 \%$ was obtained, meaning that the obtained value was partially attained. It was assessed from the policies and quality guidelines regarding aqidah, worship, morals and religion, sharia services, Islamic quality, recording and reporting, and the Islamization program of the sharia hospital, which was partially achieved.

\section{Assessment Results for Sharia Service} Standards

Table 6. Sharia Standards for Service Access and Continuity (SSAPK)

\begin{tabular}{|l|c|c|c|c|c|}
\hline Standard & Obtained value & $\begin{array}{c}\text { Maximum standard } \\
\text { of the obtained value }\end{array}$ & $\begin{array}{c}\text { Average } \\
\text { obtained value }\end{array}$ & $\begin{array}{c}\text { Achievements } \\
(\%)\end{array}$ & Description \\
\hline SSAPK & 55 & 60 & 9,17 & 91,7 & High \\
\hline
\end{tabular}

The assessment result displayed in Table 6 above shows the obtained value as follows:
Analysis of the Sharia Service Standard Group consisted of (1) Sharia Standards for Service Access and Continuity (SSAPK), (2) Sharia Standards for Patient Assessment (SSAP), (3) Sharia Standards for Patient Services (SSPP), (4) Sharia Standards for Drug Services (SSPO), (5) Sharia Standards for Services and Spiritual Guidance (SSPBK), and (5) Sharia Standards for Patient and Family Education (SSPPK).

\section{The results of the Sharia Standard Service}

Access and Continuity Assessment (SSMM) are presented in Table 6 below:
From the aspect of standard operating procedures for patient admission, guidance, discharge, and completeness of transportation using Islamic audio or video media, the value was $91.7 \%$. It indicated that the 
obtained value was fully reached, assessed from the procedure for admission, guidance, patient discharge, provision. Islamic values, and the acceptance of guidance books in accordance with the standards of the sharia hospital.
The results of the Sharia Standard Patient Assessment (SSAP) are displayed in Table 7 below:

Table 7. Sharia Standards for Patient Assessment (SSAP)

\begin{tabular}{|l|c|c|c|c|c|}
\hline Standard & Obtained value & $\begin{array}{c}\text { Maximum standard } \\
\text { of the obtained value }\end{array}$ & $\begin{array}{c}\text { Average } \\
\text { obtained value }\end{array}$ & $\begin{array}{c}\text { Achievements } \\
(\%)\end{array}$ & Description \\
\hline SSAP & 30 & 30 & 10,00 & 100 & High \\
\hline
\end{tabular}

The assessment result presented in Table 7. reveals the obtained value as follows:

From the patient's spiritual aspect, a value of $100 \%$ was obtained, meaning that the obtained value was fully achieved. It was judged by the guidelines and procedures for the patient's spiritual assessment, psychospiritual services, and spiritual assessment in accordance with the standards of the sharia hospital.

The results of the Sharia Standard Patient Service Assessment (SSPP) are presented in Table 8 below:

Table 8. Sharia Standards for Patient Services (SSPP)

\begin{tabular}{|l|c|c|c|c|c|}
\hline Standard & $\begin{array}{c}\text { Obtained } \\
\text { value }\end{array}$ & $\begin{array}{c}\text { Maximum } \\
\text { standard of the } \\
\text { obtained value }\end{array}$ & $\begin{array}{c}\text { Average } \\
\text { obtained value }\end{array}$ & $\begin{array}{c}\text { Achieveme } \\
\text { nts (\%) }\end{array}$ & Description \\
\hline SSPP1 & 40 & 40 & 10,00 & 100 & High \\
\hline SSPP2 & 40 & 40 & 10,00 & 100 & High \\
\hline SSPP3 & 50 & 50 & 10,00 & 100 & High \\
\hline SSPP4 & 40 & 40 & 10,00 & 100 & High \\
\hline SSPP5 & 15 & 20 & 7,50 & 75 & High \\
\hline SSPP6 & 40 & 40 & 10,00 & 100 & High \\
\hline SSPP7 & 20 & 20 & 10,00 & 100 & High \\
\hline
\end{tabular}

The assessment results displayed in Table 8. show the obtained values as follows:

1) From the aspect of standard policies and procedures for High-Risk Patient Services, a value of $100 \%$ was obtained, meaning that the obtained value was fully achieved, assessed from the policies and procedures for high-risk patient services in accordance with the standards of sharia hospitals.

2) From the aspects of the standard of halal assurance, hygiene, food safety, and nutritional therapy given to patients, a value of $100 \%$ was obtained, meaning that the obtained value was fully achieved, assessed from insurance, halal food service, and nutritional therapy to patients in accordance with the standards of sharia hospitals.

3) From the standard aspect of guaranteeing the care of the patient's genitals, services according to sex, and maintaining the ikhtilath element, a value of $100 \%$ was obtained, meaning that the obtained value was fully achieved, especially in services according to the patient's gender. There were limitations, but it was still within the MUI tolerance, and the overall assessment results were in accordance with sharia hospital standards.
4) From the aspect of anesthesia and surgical service assurance standards according to sharia, a value of $100 \%$ was obtained, meaning that the obtained value was fully achieved, assessed from the assurance of conformity for surgical anesthesia services in accordance with sharia hospital standards.

5) From the aspect of Ruqyah syar'iyah management service standards, a score of $100 \%$ was obtained, meaning that the obtained value was fully achieved, assessed from the management service of Ruqyah syar'iyah to be in accordance with sharia hospital standards.

6) From the aspect of the standard of maternal and infant health services according to sharia, a value of $100 \%$ was obtained, meaning that the obtained value was fully achieved, assessed from the health services provided for mothers and babies in accordance with the standards of sharia hospitals.

7) From the aspect of Islamic reproductive health service standards, a value of $100 \%$ was obtained, meaning that the obtained value was fully achieved, assessed from Islamic reproductive health services in accordance with the standards of sharia hospitals. 
Table 9. Sharia Standards for Drug Services (SSPO)

\begin{tabular}{|l|c|c|c|c|c|}
\hline Standard & Obtained value & $\begin{array}{c}\text { Maximum } \\
\text { standard of the } \\
\text { obtained value }\end{array}$ & $\begin{array}{c}\text { Average } \\
\text { obtained } \\
\text { value }\end{array}$ & $\begin{array}{c}\text { Achievements } \\
(\%)\end{array}$ & Description \\
\hline SSPO & 35 & 40 & 8,75 & 87,5 & High \\
\hline
\end{tabular}

The assessment result presented in Table 9. shows the obtained value as follows:

From the standard aspect of striving for drug formularies not to contain prohibited elements and always conveying religious messages when administering drugs to patients, the score was $87.5 \%$. It denoted that the obtained value was close to being fully attained, which was judged by seeking a medicinal formula that did not contain prohibited elements; in this case, it was necessary always to review the medicinal formula. For religious messages to patients, the hospital efforts were considered to be in accordance with sharia hospital standards.

The results of the Sharia Standard Assessment of Services and Spiritual Guidance (SSPBK) are presented in Table 10 below:

Table 10. Sharia Standards for Services and Spiritual Guidance (SSPBK)

\begin{tabular}{|l|l|l|l|l|l|}
\hline Standard & Obtained value & $\begin{array}{l}\text { Maximum } \\
\text { standard of the } \\
\text { obtained value }\end{array}$ & $\begin{array}{l}\text { Average obtained } \\
\text { value }\end{array}$ & Achievements (\%) & Description \\
\hline SSPBK1 & 20 & 10,00 & 100 & High \\
\hline SSPBK2 & 20 & 20 & 10,00 & 100 & High \\
\hline SSPBK3 & 20 & 40 & 8,75 & 87,5 & High \\
\hline SSPBK4 & 35 & 20 & 10,00 & 100 & High \\
\hline SSPBK5 & 20 & 30 & 10,00 & 100 & High \\
\hline SSPBK6 & 30 & 9,00 & 90 & High \\
\hline
\end{tabular}

The assessment results displayed in Table 10 show the obtained values as follows:

1) From the aspect of the standard of Islamic spiritual guidance to patients, a value of $100 \%$ was obtained, meaning that the obtained value was fully achieved as assessed by the efforts of Islamic spiritual guidance to patients in accordance with the standards of a sharia hospital.

2) From the aspect of the standard of Islamic spiritual guidance to patients, a value of $100 \%$ was obtained, meaning that the obtained value was fully achieved as assessed by the efforts of Islamic spiritual guidance to patients in accordance with the standards of a sharia hospital.

3) From the standard aspect of Islamic spiritual guidance to patients, it was obtained a value of $87.5 \%$, meaning that the obtained value was close to being fully achieved, judging from the efforts of Islamic spiritual guidance to patients in accordance with the standards of sharia hospital
4) From the aspect of the standard of Islamic spiritual guidance to patients, a value of $100 \%$ was obtained, meaning that the obtained value was fully achieved as assessed by the efforts of Islamic spiritual guidance to patients in accordance with the standards of a sharia hospital.

5) From the aspect of the standard of Islamic spiritual guidance to patients, a value of $100 \%$ was obtained, meaning that the obtained value was fully achieved as assessed by the efforts of Islamic spiritual guidance to patients in accordance with the standards of a sharia hospital.

6) From the aspect of the standard of Islamic spiritual guidance to patients, a value of $100 \%$ was obtained, meaning that the obtained value was fully achieved as assessed by the efforts of Islamic spiritual guidance to patients in accordance with the standards of a sharia hospital.

The results of the Sharia Standard Assessment for Patient and Family Education (SSPPK) are presented in Table 11 below:

Table 11. Sharia Standards for Patient and Family Education (SSPPK)

\begin{tabular}{|l|c|c|c|c|c|}
\hline Standard & Obtained value & $\begin{array}{c}\text { Maximum } \\
\text { standard of the } \\
\text { obtained value }\end{array}$ & $\begin{array}{c}\text { Average } \\
\text { obtained value }\end{array}$ & $\begin{array}{c}\text { Achievements } \\
(\%)\end{array}$ & Description \\
\hline SSPPK1 & 35 & 40 & 8,75 & 87,5 & High \\
\hline SSPPK2 & 20 & 20 & 10,00 & 100 & High \\
\hline SSPPK3 & 20 & 20 & 10,00 & 100 & High \\
\hline
\end{tabular}




\begin{tabular}{|l|c|c|c|c|c|}
\hline SSPPK4 & 20 & 20 & 10,00 & 100 & High \\
\hline SSPPK5 & 20 & 30 & 6,66 & 66,6 & High \\
\hline
\end{tabular}

The assessment results are presented in Table 11., showing the obtained values as follows:

1) From the aspect of Islamic education standards to patients and families regarding the healing process of diseases, the value was $87.5 \%$. It means that the obtained value was close to being fully achieved, judging from the Islamic education efforts of patients and families regarding the healing process of disease in accordance with the standards of sharia hospitals.

2) From the standard aspect of providing library facilities containing Islamic literature, the value was $100 \%$. It means that the obtained value was fully achieved, assessed from the efforts to provide Islamic library facilities to patients in accordance with the standards of sharia hospitals.

3) From the aspect of the standard for resolving conflict complaints or disagreements in sharia, the value was $100 \%$. It means that the obtained value was fully achieved as assessed from efforts to resolve conflict complaints in accordance with sharia hospital standards.

4) From the aspect of sustainable Islamic Health Education and Training Standards, a score of $100 \%$ was obtained. It means that the obtained value was fully achieved, assessed from the efforts of continuous health education and training for patients in accordance with sharia hospital standards.

5) From the aspect of Islamic education standards to visitors, the value was $66.6 \%$. It means that the obtained value was achieved while still needs to be maximized, judging from the availability of guides on Islamic education to visitors, educational posters, and others for visitors in accordance with the standards of sharia hospitals.

\section{CONCLUSION AND SUGGESTION CONCLUSION}

From the analysis results conducted at the " $\mathrm{X}$ " Hospital in Bantul, Yogyakarta, it could be concluded as follows:

1. The management of Hospital " $\mathrm{X}$ " in Bantul Yogyakarta has met a Sharia hospital's requirements because it has implemented the principles of Maqashid Syariah so that it can become an example for other hospitals in Indonesia. These results are supported by the assessment results for each of the Sharia Management Standards and Sharia Service Standards at the "X" Hospital.

2. The performance of " $\mathrm{X}$ " Hospital Services in Bantul, Yogyakarta is as follows:
The results of the Hospital Performance Assessment based on the Sharia Management Standard Group are:

1) In the Organization Management Sharia Standard (SSMO), the assessment results showed that the obtained value had been fully achieved.

2) In the Marketing Management Sharia Standard (SSMP), the assessment results showed that the obtained value was fully achieved.

3) In the Sharia Standard for Facility Management (SSMF), the assessment results showed that the obtained value was partially achieved.

4) In the Sharia Standard for Quality Management (SSMM), the assessment results showed that the obtained value was fully achieved.

The results of the hospital performance assessment based on the Sharia Management Standard Group are:

1) For Sharia Standards for Service Access and Continuity (SSAPK), the assessment results stated that the obtained value was fully achieved.

2) For Patient Assessment Sharia Standards (SSAP), the assessment results stated that the obtained value was declared fully achieved.

3) For Patient Service Sharia Standards (SSPP), the assessment results stated that the obtained value was declared fully achieved.

4) For the Sharia Standard for Drug Services (SSPO), the assessment results stated that the obtained value was moderate and has only been partially achieved.

5) For Sharia Standards for Services and Spiritual Guidance (SSPBK), the assessment results stated that the obtained value was fully achieved.

6) For Patient and Family Education Sharia Standards (SSPPK), the assessment results stated that the obtained value was fully achieved.

\section{SUGGESTION}

1. The assessment results on Sharia Management Standards that have not been maximal include the Marketing Management Sharia Standards (SSMP), Facility Management Sharia Standards (SSMF), and Quality Management Sharia Standards (SSMM), so they still need to be completed and improved. For an assessment of the Sharia Standards for Organizational Management, which has been good and maximum, it needs to be maintained. 
2. The assessment results on Sharia Service Standards, which are not yet optimal, are the Sharia Service Standards for Medicine (SSPO), and the obtained value was stated to be moderate so that it still needs to be improved. Meanwhile, for other Sharia service standard, which has been good and maximal, it needs to be maintained.

\section{REFERENCES}

[1] Rizqon et al., "Sharia Services With A Level Of Patient Satisfaction In Hospitals: Literature Review" Nursing Journal of Respati Yogyakarta, 7(1), January 2020, 26-302019.

[2] Ismail, et al., Journey to Shariah Hospital: "An Indonesian Experience", International Journal of Human and Health Sciences Vol. 02 No. 02 April'18, page 56.

[3] Abdurrahman dan Sulistiadi, "Sharia Hospital as An Added Value: A Systematic", The 6th International Conference on Public Health Best Western Premier Hotel, Solo, Indonesia, October 23-24, 2019.

[4] MUKISI, "Buku Pedoman Standar Pelayanan Minimal Syariah dan Indikator Mutu Wajib Syariah, 2017.

[5] Abdurrouf dan Rosalia, "Pelayanan Syariah Dalam Bidang Keperawatan Dengan Tingkat Kepuasan Pasien di Rumah Sakit", Proceeding Unissula
Nursing Conference Tema: "Nurse Roles in Providing Spiritual Care in Hospital, Academic and Community", 2018, p-24.

[6] Sumadi, "Peran Manajemen Syariah Terhadap Peningkatan Kepuasan Pelanggan Pada Rumah Sakit Islam Di Kota Surakarta", Jurnal Ilmiah Ekonomi Islam Vol. 03 No. 02, 2017, p-112.

[7] Pribadi, Ulung, Nilai-Nilai Agama dan Pelayan Publik, Studi kasus di Rumah Sakit Muhammadiyah Yogyakarta, 2012

[8] Syarif SM, Rahman ARA, "Shari'ah Compliant Hospital; From Concept to Reality: A Malaysian Experience, Bangladesh Journal Ilmu Kedokteran, Volume 15, No: 01 Januari, 2016.

[9] Standar dan Instrumen Sertifikasi Rumah Sakit Syariah-versi 1438.

[10] Pahlawi and Fatonah," The Role of Leadership in Improving Performance Through Organization Commitment, Motivation and Job Satisfaction of Village Employees", Jurnal Manajemen Bisnis, Vol 11 No 1 (2020), 106.

[11] Sulistyadi, W, dan Rahayu, "Potensi Penerapan Maqashid Syariah dalam Rumah Sakit Syariah di Indonesia”, Batusangkar Internasional Confrence, 2016. 